\title{
Hermeneutika Hans-Georg Gadamer: Studi Analisis Kritis Penafsiran Amina Wadud tentang Ayat Kepemimpinan
}

\author{
Moh. Isom Mudin ${ }^{1 *}$, Muhammad Dhiaul Fikri², Munar Moh Shobirin ${ }^{3}$, \\ Rohmah Akhirul Mukharom ${ }^{4}$ \\ 1,2,3,4 Universitas Darussalam Gontor Ponorogo, Indonesia
}

\begin{abstract}
Abstrak: Penelitian ini bertujuan untuk mengkaji tentang munculnya upaya penerapan hermeneutika sebagai pendekatan penafsiran al-Qur' an yaitu yang dikembangkan oleh Hans-Georg Gadamer dengan istilah Wirkungsgeschichte. Teori ini berhasil memikat Amina Wadud Muhsin untuk mengadopsi demi mencapai kepentingan dan tujuan tertentunya. Metode penelitian yang digunakan adalah kepustakaan. Penelitian ini menyimpulkan bahwa hermeneutika Hans-Georg Gadamer jelas bermasalah dan tidak mungkin diaplikasikan dalam penafsiran Islam karena ia bersumber dari tradisi ahli kitab dalam memahami kitab suci mereka. Jika hermeneutika dipaksakan untuk menafsirkan ayat-ayat al-Qur'an, maka sama saja ingin menjadikannya sebagai alat untuk mengkritisi ayat-ayat dalam al-Qur'an.
\end{abstract}

Kata Kunci: Hermeneutika, Wirkungsgeschichte, Penafsiran al-Qur'an, Amina Wadud

\begin{abstract}
This study aims to examine the emergence of efforts to apply hermeneutics as an approach to interpreting the Qur'an, which was developed by Hans-Georg Gadamer with the term Wirkungsgeschichte. This theory succeeded in luring Amina Wadud Muhsin to adopt it in order to achieve certain interests and goals. The research method used is literature. This study concludes that Hans-Georg Gadamer's hermeneutics is clearly problematic and impossible to apply in the interpretation of Islam because it comes from the tradition of the scribes in understanding their holy book. If hermeneutics is forced to interpret the verses of the Qur'an, then it is the same as wanting to use it as a tool to criticize the verses in the Qur'an.
\end{abstract}

Keywords: Hermeneutics, Wirkungsgeschichte, Interpretation of the Qur'an, Amina Wadud

\section{Pendahuluan}

Hermeneutika modern perlu dikaji ulang dikarenakan sampai saat ini, hermeneutika digunakan sebagai pendekatan Islamic studies. Hal tersebut tidak terlepas dari kegelisahan yang berlaku dalam kalangan umat Islam. Ia merupakan sebuah tradisi khas keilmuan yang lahir dari rahim ideologi Barat, dan terikat dengan nilai-nilai tertentu dari peradaban mereka. Setidaknya terdapat beberapa alasan utama, mengapa diskursus tersebut perlu untuk ditelaah kembali secara serius; pertama, sebagai sebuah metode filosofis, universalitas hermeneutika masih menjadi perdebatan dialektis oleh para pengusungnya (Gadamer, 1975). Kedua, ia lahir dari iklim kultural ilmiah Barat modern (scientific environment) yang kritis terhadap keyakinan metafisis. Ketiga, dalam sejarahnya, ia merupakan sebuah metode

\footnotetext{
* Corresponding Author: Munar Moh Shobirin (munarafi@mhs.unida.gontor.ac.id). Universitas Darussalam Gontor Ponorogo, Indonesia
}

p-ISSN 1412-1697; e-ISSN 2477-3816

http://jurnal.radenfatah.ac.id/index.php/intizar 
interpretasi yang diadopsi para teolog Kristen sebagai Tafsir Bible secara bebas (Zarkasyi, 2004).

Ketika memasuki abad ke-20, hermeneutika mengalami pergeseran yang sangat signifikan yaitu dari ranah teologis ke ranah filsafat (Audi, 1999). Pergeseran tersebut, ditandai dengan masifnya cara pandang sekular-liberal yang turut andil mewarnai dan berkontribusi atas pemaknaan model baru dalam diskursus hermeneutika modern (Faiz, 2015). Kegelisahan tersebut seharusnya perlu disadari oleh para sarjana Muslim agar bersikap arif dan lebih teliti jika hendak ingin menggunakan pendekatan hermeneutis, menggantikan salah satu metode keilmuan Islam, yaitu penafsiran alQur'an.

Salah satu metode hermeneutika yang sering mendapat perhatiannya ialah hermeneutika filosofis yang dikembangkan oleh Hans-Georg Gadamer, dalam magnum opus-nya 'Wahrheit und Method'. Dari karyanya tersebut, ia kemudian dikenal sebagai bapak filsuf hermeneutika modern dunia (B. Hardiman, 2015). Dalam salah satu bagian buku tersebut, ia menawarkan sebuah teori untuk mencapai sebuah kesepahaman atau pemahaman terhadap teks (baik suci maupun non-suci) yang dikenal dengan 'afective history' atau dalam istilah yang sering digunakan 'Wirkungsgeschichte' (Gadamer, 1975). Teori tersebut menjelaskan, tiap pemahaman terhadap teks tidak ada yang obyektif, karena penafsir dipengaruhi oleh unsur budaya sekitar yang mengitarinya (Gadamer, 1975). Jika teori itu diterapkan dalam penafsiran al-Qur'an, maka akan berimplikasi pada relativisme tafsir. Karena penafsir terpengaruh oleh situasi tertentu dalam menafsirkan ayat al-Qur'an.

Keberhasilan metode hermeneutik modern dalam menginterpretasi bible, tampaknya berhasil memikat salah satu tokoh pemerhati feminis Muslim kontemporer, yaitu Amina Wadud. Ia tertarik untuk menggunakan metode hermeneutis Gadamer, untuk ia pergunakan sebagai salah satu pendekatan tafsir kontemporer, khususnya ayatayat yang bias terhadap gander. Sebagai seorang aktivis feminis, ia memang kerap melontarkan pemikiran-pemikiran kritisnya terhadap pemahaman keagamaan yang tampak diskriminatif terhadap perempuan (Irsyadunnas, 2017). Dalam salah satu karyanya 'Qur'an and Women' ia menyatakan kritiknya terhadap penafsiran ulama, bahwa penafsiran yang dilakukan cendrung dilakukan dengan pengalaman oleh laki-laki, tanpa mengikutsertakan pengalaman perempuan, hasilnya terkesan diskriminatif dan menunjukkan superioritas laki-laki atas perempuan.

Sebagai contoh, dalam penafsiran makna 'qawwam' dalam surat an-Nisa: 43. Menurut Amina Wadud makna 'qawwam' tidak harus ditafsirkan sebagai 'pemimpin' dengan berbagai macam alasan dilatarbelakangi oleh ketimpangan gander dalam penafsiran al-Qur'an tersebut, hal tersebut menjadi dorongan penuh bagi dirinya untuk melakukan reinterpretasi makna baru terhadap penafsiran makna 'qawwam', dengan meminjam langkah corak hermeneutik Gadamer sebagai pendekatannya (Wadud, 1999). Meski ia tidak mengatakan secara tegas di dalam karyanya terpengaruh oleh Gadamer, melainkan oleh Fazlur Rahman. Namun, usaha Fazlur Rahman sejatinya merupakan anjuran dari Gadamer karenanya pemikiran Gadamer sedikit banyak turut mewarnai corak pemikiran metodik yang dikembangkan Fazlur Rahman (Sibawahi, 2007).

Kajian ini bertujuan untuk menjelaskan secara kritis, metode hermeneutika yang dikembangkan oleh Gadamer yang digunakan sebagai basis interpretasi teks dan aplikasinya terhadap penafsiran al-Qur'an. Dalam aplikasinya tersebut, penelitian ini akan merujuk pada satu 
kasus model penafsiran Amina Wadud Muhsin, khususnya di dalam ayat kepemimpinan laki-laki.

Kajian tentang hermeneutika Garamader telah diteliti oleh beberapa penelitian di antaranya Kaprisma (2011) mengulas secara kritis estetika modern dan teori pemahaman historis dan perspektif Heideggerian, sehingga ditemukan bahwa penafsir yang menggunakan teori ini melakukan pemahaman teks yang hadir dengan mengkaitkan lingkup historis cakrawala teks tersebut. Sehingga proses penafsiran tidak memproduksi makna tetapi makna yang melampaui teks. Sehingga ditemukan makna utuh. Selanjutnya oleh Sofyan (2014) menemukan bahwa menurut Gamader membaca dan memahami sebuah teks pada dasarnya adalah melakukan dialog dan membangun sintesis antara dunia dan teks, dunia pengarang dan pembaca dan direlevansikan dengan empat teori dalam lingkaran hermeneutika gamader yang bukan menjadi hal baru dalam tafsir. Sehingga hermeneutika adalah teori penafsiran. Karena tetap berbeda pada sisi teologisnya. Selain diteliti sebagai tafsir hermeneutika juga diteliti dalam kajian hokum oleh Kushidayati (2014) hermeneutika merupakan alat analisis dalam ilmu sosial yang dapat digunakan dalam studi tentang hukum termasuk hukum Islam. Menurut Gamader, hukum mampu dipahami dengan hermeneutika sebagai teks tidak lepas dari cakrawala yang melingkupinya. Sedangkan penelitian ini akan menunjukkan betapa rancunya hermeneutika Gadamer dengan mengusung satu kasus yaitu penafsiran Amina Wadud dalam ayat kepemimpinan.

\section{Metode}

Kajian ini merupakan penelitian penelitian kualitatif (Sugiyono, 2012) dan dengan metode deskriptif analisis kritis. Penelitian ini akan mendeskripsikan corak hermeneutika Gadamer beserta karakteristiknya. Dan kemudian menganalisis serta memberikan kritik terhadap pengaplikasian teori tersebut — sebagaimana yang dilakukan oleh Amina Wadud dalam penafsiran ayat al-Qur'an, khususnya dalam ayat kepemimpinan laki-laki.

\section{Hasil dan Pembahasan}

Secara etimologis, 'hermeneutik' atau 'hermeneutika' meruapakan serapan dari kata Inggris hermeneutics (F. B. Hardiman, 2012). Ia memiliki asal kata dari Yunani hermeneuin, artinya 'menafsirkan'. Secata harfiah hermeneia dapat diartikan dengan 'penafsiran'. Kata tersebut, sering dihubungkaitkan dengan mitos Yunani kuno, yaitu dewa 'Hermes' yang merupakan utusan (Zeus) Tuhan untuk menterjemahkan dan mengantarkan pesan-pesan dari para dewa, yang kemudian ia transmisikan ke dalam bentuk pemahaman bahasa akal fikiran manusia (Palmer, 1977). Tujuan utamanya ialah, agar manusia dapat mengerti dan memahami pesan Tuhan serta menyatu denganNya (Preus, 2007). Dari sinilah makna awal hermeneutika lahir, yaitu sebagai penafsiran mitologi Yunani yang dilakukan oleh Hermes.

Memasuki abad ke-20, ruang lingkup hermeneutika menjadi semakin luas. Friedrich Schleiermacher, berhasil memperluas wilayah hermeneutika dari yang sebelumnya di abad pertengahan hanya sebatas alat interpretasi teks suci, mulai diperluas memasuki wilayah-wilayah non-religius. Upaya itu dikenal dengan istilah Universal Hermeneutic (Palmer, 1977). Pada konteks ini, kedudukan teks disamaratakan kedudukannya, tidak ada yang dikultuskan kedudukannya; baik itu teks suci, maupun teks karangan manusia (Arif, 2008). Selanjutnya, pemikiran yang dikembangkan oleh Schleiermacher, membuka pintu bagi para pemikir hermeneutis dikemudiannya; seperti Wilhelm 
Dilthey yang memfokuskan gagasannya pada 'historisitas teks' serta urgensinya akan sebuah 'kesadaran sejarah' (Arif, 2008). Selain itu, Martin Heidegger, Hans-Georg Gadamer, Jurgen Habermas, dan Paul Ricour juga turut mengembangkan corak tersendiri yang dikenali sebagai hermeneutik modern (Bachtiar, 2017).

Perkembangan hermeneutika yang bermula dari klasik hingga modern. Dalam kemunculannya, ia mengalami tiga periodik sejarah. Permulaan hermeneutika berangkat dari tradisi keagamaan atas mitologi Yunani. Penafsiran-penafsiran mitologi tersebut sangat subyektif, karena ditentukan oleh kondisi keagamaan yang berlaku. Dan metode yang sering digunakan saat itu ialah metode kiasan (allegorical method). Dan dalam penafsiran tersebut umumnya sangat menolak penafsiran secara literer, bahkan meninggalkannya (Wan Daud, 2004)

Selanjutnya, hermeneutika bergeser menjadi sebuah tradisi yang digunakan oleh teolog YahudiKristen untuk menafsirkan Bible secara kritis. Hal itu tidak luput dari problem Bible yang problematis, baik dari segi penulisan Bible, permasalahan pembukuannya, hingga kontradiksi antara satu ayat dengan ayat lainnya yang saling bertentangan. Sehingga, para sarjana tersebut perlu meminjam model penafsiran mitologi Yunani tersebut. Dan memasuki abad modern, ia kembali bergeser menjadi bagian dari metode filsafat yang menempatkan objek penafsiran sebagai sesuatu yang tidak sakral. Hal itu juga tidak luput dari perdebatan panjang antara Katolik dan Protestan serta lahirnya pengaruh ideologi Barat (Sekularisme) pasca abad pertengahan, yang ingin lepas dari pengaruh otoritas Gereja di abad pertengahan. Artinya, metode hermeneutika memiliki pengaruh hingga memunculkan perdebatan besar antara Kristen Katolik dan
Protestan di abad pertengahan, yang pada akhirnya behasil dikuasai oleh Protestan Liberal.

\section{Hermeneutika Hans-Georg Gadamer: Pandangan Umum Hermeneutika Gadamer}

Hans-Georg Gadamer dilahirkan di kota Marburg Jerman, 11 Feb 1900. Kebesarannya sebagai seorang filusuf tidak terlepas dari didikan gurunya yaitu Martin Heidegger (B. Hardiman, 2015). Dalam magnum opus-nya, Truth and Method yang semula ditulis dalam bahasa Jerman Wahrheit und Method, telah memberikan pengaruh cukup besar bagi perkembangan ilmu-ilmu sosial (social sciences). Dari konstribusi besarnya tersebut, ia kemduian dikelompokkan pada pemikir hermeneutik modern (Rahardjo, 2007).

Dalam hermeneutika filosofisnya, Gadamer memiliki pandangan yang berbeda dengan para pendahulunya. Jika Schleiermacher memusatkan hermeneutikanya sebagai sebuah seni memahami keasingan teks-teks kuno yang bertujuan untuk menghindari kesalahpahaman terhadap teks tersebut, dengan cara memahami interpretasi pengarang jauh lebih baik daripada dirinya (Nayed, 1994). Artinya, di sini ada upaya rekonstruksi makna teks masa silam agar tercapai sebuah pemahaman murni. Maka berbeda halnya dengan Gadamer, untuk memahami teks bukanlah dengan merekonstruksi makna teks masa silam, akan tetapi dengan upaya peleburan antara teks masa lalu dengan horizon masa kini dari pembaca sehingga memunculkan makna baru dari teks silam agar relevan untuk konteks kekinian. Istilah tersebut dikenalkan oleh Gadamer dengan sebutan Horizontverschmelzung (Gamader, n.d.).

Selanjutnya, Gadamer juga mengomentari Wilhelm Dilthey. Dilthey melakukan pendekatan dengan metode mazhab sejarahnya dalam memahami teks lampau. Menurutnya, terlepas dari unsur-unsur apapun itu, jika pembaca mendalami 
peristiwa sejarah teks di masa lampau, maka ia akan menghasilkan sebuah pemahaman yang obyektif. Pandangan tersebut berbeda dengan Gadamer. Gadamer mengkritik pendekatan sejarah yang dilakukan mazhab Dilthey, sejatinya peneliti atau penafsir sejarah teks tidak berada keluar dari pengaruh sejarah melainkan ia berada dalam situasi sejarah itu sendiri.

Artinya pembaca itu berada dalam keadaan menyejarah. Istilah ini dikenalkan oleh Gadamer dengan teorinya Wirkungsgeschichte (Gadamer, 1975). Dengan demikian Gadamer tidak menjadikan hermeneutika sebagai sebuah seni ataupun sebagai metode. Dalam kata pengantar bukunya 'Truth and Method' ia mengatakan, "I did not intend to produce a manual for guding understanding in the manner of the earlier hermeneutics. I did not wish to elaborate a system of rules to describe, let alone direct, the methodical procedure of the human sciences." (Gadamer, 1975).

Jelas di sini, Gadamer tidak sedang memformulasikan corak hermenutikanya sebatas seni interpretasi subyektif, melainkan sebuah cara pandang seseorang yang diperoleh melalui akumulasi pengalamannya dari realitas (Gadamer, 1975). Di sini, mengikut sertakan seluruh pengalaman seorang pembaca akan eksistensinya sebagai makhluk, inilah yang membedakan corak hermenutika Gadamer dengan para pendahulunya, dan karenannya tergolong dengan 'hermeneutika filosofis'.

\section{Teori Hermeneutika Gadamer}

Gadamer menawarkan beberapa teori di dalam bukunya 'Wahrheit und Methode', yang mengangkat ia sebagai seorang filsuf hermeneutika modern. Di antaranya, Pertama Prasangka (Vorurteil). Gadamer terlebih dahulu menjelaskan sebuah teori pra-struktur memahami yang ditilik dari Heidegger. Ia sepakat dengan pra-struktur memahami yang dikembangkan oleh gurunya tersebut. Cara interpretasi dengan konteks sebuah proyeksi yang ditawarkan Heidegger diantaranya, Pertama: 'Vorsicht' yang berarti, 'kewaspadaan' atau bisa juga dimaknai 'melihat lebih dahulu'.

Maksudnya jika melihat sebuah makna teks, yang harus dilakukan adalah tidak kembali pada makna masa lalu teks tersebut akan tetapi kita bersandar pada makna yang telah kita milliki sendiri untuk masa depan. Kedua, 'Vorhabe' yang artinya 'rencana' atau bisa juga dimaknai 'memiliki lebih dahulu'. Maksudnya, sebagai penafsir kita telah memiliki terlebih dahulu pemahaman umum baik ide-ide, konsep-konsep, dan sebagainya, yang akan membantu sebagai proyeksi masa depan (B. Hardiman, 2015).

Ketiga: 'Vorgriff' yang artinya, 'antisipasi' atau bias juga dimaknai 'menangkap lebih dahulu'. Maksudnya, seorang penafsir menangkap makna lebih dahulu atau telah mengetahui pesan teks yang akan ia sampaikan agar relevan bagi dirinya dan untuk zamannya. Dengan seperti itu, interpretasi bukanlah mencari objektivitas, melainkan melahirkan menyingkap makna bagi masa depan Seorang yang mencoba memahami sebuah teks selalu didahului dengan sebuah pra-pemahaman dari pembaca itu sendiri. sehingga si pembaca tersebut dituntut untuk tidak memahami makna teks dari masa silamnya, akan tetapi dengan prapemahaman yang telah dimiliki, ia gunakan sebagai upaya produksi makna baru dari teks masa lalu, agar relevan bagi dirinya dan untuk masa depannya (Gadamer, 1975).

Sebagai contoh, ketika mendapati sebuah surat dari masa lampau, setidaknya seorang pembaca tersebut tidak menerima secara utuh makna dari isi surat tersebut, akan tetapi, 
semampunya untuk menyesuaikan makna surat tersebut dengan sebuah proyeksi awalnya atau prapemahamannya, agar lebih bermanfaat dengan kekinian (Gadamer, 1975). Jika memahami teks selalu melibatkan makna yang telah ada dari sebelumnya, maka pemahaman tersebut tidaklah obyektif, karena makna teks itu, juga merupakan hasil dari pra-pemahaman si pembuat teks di masa lalunya. Obyektifitas hanya akan didapat dengan mengakui akan adanya proyeksi pra-pemahaman makna yang berkerja sebelum muncul sebuah interpretasi, karenanya upaya pra-pemahaman atau proyeksi tidaklah mungkin dipisahkan dari gerakan pemahaman atau penafsiran (B. Hardiman, 2015).

Pra-struktur memahami di atas digunakan Gadamer untuk rehabilitasi konsep prasangka. Prasangka dalam bahasa Jerman ia disebut 'Vorurteil' atau bisa juga dimaknai sebagai 'pemberian penilaian atau pertimbangan sebelum menginterpretasikan sebuah teks'. Memasuki masa pencerahan abad ke-18, prasangka mulai didiskreditkan menjadi sesuatu yang tidak berdasar dan harus dihindarkan. Masa pencerahan sangat mencurigai adanya elemen prasangka yang disusupkan dalam sebuah karya ilmu pengetahuan. Ilmu pengetahuan yang obyektif seharusnya bias melepasakan diri dari sebuah prasangka (Gadamer, 1975). Artinya bagi pencerahan prasangka adalah sesuatu yang negatif dan mengganggu obyektivitas.

Akan tetapi, Gadamer tidak sepakat dengan pendapat pencerahan. Menurutnya, kecenderungan pencerahan untuk membersihkan segala ilmu pengetahuan dari prasangka, itu pun sebuah prasangka pencerahan yang melawan prasangka (Gadamer, 1975). Artinya, prasangka tidak dapat dipisahkan dalam pemahaman, karenanya ia merupakan komponen yang memungkinkan pemahaman (B. Hardiman, 2015). Jelas bahwa prasangka tidak mengantarkan pada kebenaran. Dalam hal ini Gadamer menyakatan bahwa prasangka dapat sampai pada nilai kebenaran, jika prasangka tersebut legitimasi. Legitimasi dalam hal ini ialah prasangka yang memiliki otoritas (Gadamer, 1975). Artinya, penafsir atau pembaca yang memiliki otoritas, baik itu wawasan yang luas, kompetensi yang mumpuni dan pengalaman yang mendalam di bidangnya, hal itu dapat membantu untuk memahami teks. Dengan demikian anggapan pencerahan yang menyatakan prasangka tidak dapat dijadikan upaya pemahaman ditolak oleh Gadamer. Karena prasangka merupakan komponen untuk sampai pada pemahaman. Prasangka tersebut ialah prasangka yang bersifat legitimasi. Kedua, pengaruh sejarah.

Menurut Gadamer, pemahaman hakikatnya adalah sebuah hubungan sejarah efektif. Karenanya, untuk mencapai sebuah pemahaman baik pada karya teks tertentu ataupun fenomena sejarah, seorang pembaca atau penafsir sejatinya harus sadar bahwa terdapat pengaruh sejarah yang selalu ada mengitarinya. Gadamer (1975) mengatakan,“.... in the apparent immediacy with which it approaches a work of art or a traditionary text, there is also another kind of inquiry in play, albeit unrecognized and unregulated. If we are trying to understand a historical phenomenon from historical distance....., we are already affected by history."

Arti bebasnya, dalam mendekati sebuah karya atau teks tradisional, sejatinya terdapat unsur lain yang ikut mempengaruhi, (baik itu kepentingan, tradisi, politik dan lainnya) meskipun tidak disadari oleh pembaca teks tersebut. Dan jika mencoba memahami fenomena sejarah dari sebuah jarak sejarah, maka kita selalu tunduk pada pengaruh-pengaruh sejarah efektif. Dengan begitu, pembaca harus menyadari adanya keterpengaruhan situasi sejarah yang mempengaruhi dalam penelitiannya meskipun sangat sulit untuk diketahui (Gamader, n.d.). Dengan demikian, sejarah itu 
harus disadari oleh pembaca teks, dan bentuk kesadaran itu adalah dengan 'kesadaran sejarah pengaruh'. Karenanya tidak ada hasil penelitian yang obyektif terlepas dari pengaruh sejarah, ia akan selalu ada dalam pemahaman pembaca terhadap teks (Gadamer, 1975).

Ketiga, penggabungan horizon (horizontverschmelzung). Unsur penting lainnya dalam teori Gadamer ialah peleburan horizonhorizon. Dalam teori inilah kedua teori di atas bekerja. Menurut Gadamer (1975) terdapat dua horizon yang harus dilebur menjadi satu yaitu horizon teks dari situasi masa lalu dan horizon pembaca atau penafsir masa kini. Berkaitan dengan hal itu Gadamer mengatakan, "Rather, understanding is always the fusion of these horiozons supposedly existing by themselves."

Dengan peleburan tersebut diharapkan, teks masa lalu dan yang hadir belakangan, dapat terus menerus dikembangkan menuju proses yang lebih bernilai untuk ke depannya. Di samping itu, peleburan dua horizon tersebut juga mengatasi ketegangan yang berlaku antar kedua teks (yang lampau dan hadir kekinian) (Gadamer, 1975). Karenanya, peleburan keduanya sangat diperlukan agar penafsiran terhadap teks selalu berkembang dan bernilai dan tidak stag. Kesadaran akan dimensi historis yang mengitari teks yang lampau tersebut, merupakan langkah awal yang harus dipahami, sebelum hendak melakukan reinterpretasi teks tersebut. Dengan begitu si penafisti dapat berdialog dengan prasangka-prasangka yang dimiliki si penulis di masa lampau. Dan setelah itu, si penafsir teks dapat mereproduksi makna teks masa lalu tersebut secara kreatif agar sesuai dengan tradisi kekiniannya (B. Hardiman, 2015).

Keempat, penerapan atau aplikasi Anwendung, Aplication. Bagi Gadamer, penafsir tidak hanya dituntut untuk memahami horizon yang mengitari teks masa lampau itu ditulis, tapi juga harus mampu melakukan tahapan akhir dari langkah hermeneutikanya, yaitu 'penerapan' atau 'aplikasi'. Menurut Gadamer terdapat tiga unsur yang harus selalu berkaitan dalam struktur memahami, yaitu; pemahaman, penafsiran, dan penerapan (Gadamer, 1975). Pada tahap ini, setelah memahami kandungan horizon-horizon teks lampau, si penafsir dapat melakukan kontekstualisasi teks. Proses ini terjadi karena adanya peleburan horizon-horizon antar kedua teks; baik horizon teks lampau maupun horizon kekinian (B. Hardiman, 2015). Tegasnya, sebagai langkah akhir corak hermeneutika Gadamer, proses 'penerapan' atau 'aplikasi' bukanlah hal yang terpisah dari metode pemahaman, ia merupakan satu-kesatuan dari sebuah pemahaman yang ada dalam coral hermeneutika.

\section{Implikasi Penerapan Hermeneutika Gadamer jika digunakan sebagai pendekatan Penafsiran al-Qur'an}

Perlu disadari secara kolektif, jika teori di atas diterapkan sebagai langkah pendekatan penafsiran al-Qur'an, maka akan menimbulkan beberapa konsekuensi logis di dalamnya;

Pertama, relativisme (Taliaferro, 2010) tafsir al-Qur'an. Jika dikaitkan dalam penafsiran alQur'an, maka paham tidak ada yang benar-benar obyektif dalam penafsiran para ulama kita terdahulu. Pada pemahaman ini, penafsiran mereka harus terbuka untuk direvisi mengikuti konteks kekinian. Bila metode ini diterapkan implikasinya ialah, tidak akan ada hukum-hukum dan ajaran yang tetap dan disepakati dalam Islam. Semuanya berubah seiring dengan selera penafsir, zaman, dan lingkungan (Shalahuddin, 2007). Dasar-dasar agama yang telah tetap (qathi') dan permanen (tsawabit) akan terkikis. Dan tentunya hal tersebut 
bertentangan dengan konsep ijma' mengenai berbagai hal pokok dalam agama (Bachtiar, 2017).

Selain itu, pernyataan relativisme tersebut sejatinya tidak bisa dipertanggung jawabkan, karena justru akan menjadi boomerang bagi dirinya sendiri dan menghancurkan pendapatnya sendiri (Arif, 2008). Padahal Gadamer sendiri mengakui kebenaran yang otoritatif, Gadamer (2010) mengatakan, "pengakuan terhadap otoritas selalu dikaitkan dengan ide bahwa otoritas tersebut irasional dan arbiter, tetapi pada prisipnya ia bisa dipandang sebagai sebuah kebenaran." Jika itu benar adanya, maka sebagai umat Islam kita berhak mengakui otoritas para Ulama terdahulu sebagai orang yang ahli dan pakar dalam ilmu tafsir seperti Ibnu Katsir, al-Imam al-Qurthubi, al-Imam alThabari, dan lainnya, dibandingkan Mohammad Arkoun, Abu Zayd, Amina Wadud, Asghar Ali Engineer yang belum terbukti kepakarannya dalam ilmu Tafsir. Selanjutnya, dengan pandangan relativisme tersebut, kebenaran yang final dalam ajaran-ajaran Islam akan terhapus.

Ia juga dapat merusak struktur pondasi tradisi keilmuan Islam yang telah kokoh diakui selama ratusan tahun lamanya. Selain itu, Islam juga akan dipahami sebagai agama sejarah, sebab kealpaan pemahaman yang tsabit, tergantikan mengikuti kemajuan zaman. Dengan demikian relativisme tafsir akan melunturkan sendi-sendi ajaran Islam yang telah baku dan final.

Kedua, curiga dan kritis atas otoritas penafsiran ulama. Curiga karena keterpengaruhan para penafsir dengan latar belakang sosial yang mengitarinya, baik itu politik, ekonomi, dan lainnya. Karena itu, penafsiran selalu subyektif dan karenanya harus selalu terbuka untuk kritik. Gagasan tersebut sejatinya sama akan upaya antiotoritas. Secara tidak langsung penafsiran al-Qur'an akan terbuka ruang luas untuk ditafsirkan oleh siapa saja yang memiliki kemampuan intelektual pribadinya. Padahal dalam ajaran Islam, penafsitan al-Qur'an bukanlah perkara mudah yang terbuka untuk siapapun, atau golongan manapun. Ada ketetapan-ketetapan yang rigid yang harus dikuasai seorang penafsir. Ketetapan tersebut ditungkan dalam bentuk syarat atau langkah dan adab yang harus dipahami dan dimiliki si penafsir.

Dalam hal ini al-Imam as-Suyuti (2003) menjelaskan, bahwasannya para ulama sepakat jika ingin menafsirkan al-Qur'an hendaknya bermula dari menafsirkan suatu ayat dengan ayat yang lainnya yang terdapat dalam al-Qur'an. Jika tidak ditemukan, maka berlanjut menafsirkan ayat alQur'an dengan as-Sunnah, karena ia merupakan keterangan bagi al-Qur'an. Kemudian, jika tidak ditemukan di as-Sunnah, maka menafsirkan alQur'an dengan dengan keterangan para mufassirin dari kalangan sahabat, tabi'in dan para ulama salaf. Adapun adab-adab mufassir, yaitu berpegang teguh dengan akidah yang haq, ikhlas tanpa ada maksud dan tujuan tertentu dan hanya mengharap rida Allah semata, memiliki ketakwaan yang tinggi, mengamalkan apa yang tertera dalam al-Qur'an, menjauhi perkataan dan hal-hal yang tercela, mudawamah berzikir kepada Allah Swt. (Husein, 2004).

Ketiga, reproduksi makna penafsiran para ulama dengan metodologi baru. Metode tafsir dengan meminjak langkah hermeneutik modern era ke-20 ini, jika diterapkan sebagai pendekatan untuk menafsirkan ayat-ayat al-Qur'an, maka pada hakikatnya justru akan menciderai beberapa ajaran pokok yang sifatnya tsabit dalam tradisi Islam. Artinya, penfasiran tersebut jauh dari kemaslahatan yang haqiqi. Ini disebabkan, langkah tersebut merupakan pemikiran spekulasi filosofis yang bersifat outsider, yang pada hakikatnya syarat akan kepentingan segolongan kelompok minoritas (Lestari, 2014). Selain itu, sumber metodologi yang 
diambil juga merupakan produk Barat yang bersifar irreligius. Muhammad Asad, mengatakan, “... so characteristic of modern Western Civilization, is as unacceptable to Christianity as it is to Islam or any other religion, because it is irreligious in its very seesnce" (Husaini, 2005). Dengan demikian metode tersebut tidak menghasilkan sesuatu yang positif. Bahkan ia cendrung mendukung penyebaran ideologi Barat (Husaini, 2010). Selain itu, hasil yang mereka peroleh juga merupakan reduksi ulang agar sesuai dengan tujuan tertentu.

Keempat, penafsiran al-Qur'an berbasiskan opini akal semata. Dalam memahami teks masa lalu, menurut Gadamer penafsir dituntut untuk memperhatikan horizon historis teks tersebut, dan selanjutnya direduksi dengan prasangka awal yang dimiliki oleh penafsir agar sesuai dengan kondisi baru di mana penafsir itu berada (kontekstualisasi). Teori tersebut sangat bias dengan penafsiran subyektif berdasarkan opini. Dalam tradisi Islam, upaya untuk menafsirkan al-Qur'an, tidaklah terbuka secara luas bagi siapa pun, dan ia bukanlah perkara remeh. Bahkan bagi Nabi sendiri pun telah memberikan peringatan dalam hadisnya; "siapa saja yang mengatakan sesuatu mengenai al-Qur'an tanpa landasan ilmu atau dengan opininya sendiri, maka ia telah memesan tempat duduknya di neraka." (Muslim, 2014).

\section{Susupan Hermeneutika Gadamer terhadap Argumen-Argumen Amina Wadud}

Hermeneutika Gadamer tampak ditemukan pada tulisan Amina Wadud dalam bukunya Qur'an and Women. Pertama, jika Gadamer mengungkapkan bahwa tidak adak penafsiran yang tidak dipengaruhi oleh situasi sejarah, ia akan selalu berada dalam sejarah (Wirkungsgeschichte) (Gadamer, 1975) maka hal serupa juga diungkapkan oleh Amina Wadud. Ia menyatakan para penafsir klasik tidak dapat melepaskan dirinya dari latar belakang pengaruh sejarah yang mewarnai penafsirannya, ia mengatakan,

“..... of course, a certain entry as a living being into a foreign culture, the possibility of seeing the world throught its eyes, is a necessary part of the process of understanding it; but if were the only aspect of this understanding, it would merely be duplication and would not entail anything new or enriching. Creative understanding does not renounce its self, its own place in time, its own culture, and it forgets nothing..."(Wadud, 1999).

Arti bebasnya, pemahaman yang kreatif tidak akan pernah terlepas dari, tradisi tempat di mana ia berada dalam suatu waktu, dan kebudayaan yang mengelilinginya. Dengan demikian, menurut Amina Wadud, setiap pemahaman para mufassir terhadap teks, termasuk al-Qur'an sangat dipengaruhi tradisi ataupun budaya sekitarnya (Wadud, 1999). Dapat disimpulkan, penafsiran para ulama klasik dengan menggunakan metode konvensional tersebut tidak ada yang objektif ia mengatakan "No method of Qur'anic exegesis is fully objective" (Wadud, 1999). Karenanya, teks alQur'an dapat direinterpretasi terus menerus mengikuti konteks perkembangan zaman yang ada.

Kedua, Amina Wadud menegaskan untuk mencapai pada sebuah kesepahaman teks masa lalu, maka peran pengalaman perempuan dalam prasangka terhadap teks harus diikutkan. Karenanya, ayat-ayat yang berkaitan dengan tema perempuan, sebaiknya mengikut sertakan penglaman perempuan di dalamnya agar tidak terjadi prasangka yang bias (Wadud, 1999). Inilah tujuan yang ingin dilakuakn Amina Wadud, untuk meninjau kembali penafsiran al-Qur'an yang memperhatikan permasalahan modern termasuk isu tentang perempuan (Wadud, 1999), ia mengatakan: 
'I propose to make a 'reading' of the Qur'an from within the famale experience and without the stereotypes which have been the framework for many of the male interpretation."

Ketiga, perlunya peleburan horizon teks dan horizon penafsir teks. Amina Wadud menjelaskan jika tujuan utama yang ingin dicapai ialah, berusaha membuat interpretasi al-Qur'an menjadi bermakna dalam kehidupan kaum wanita di era modern. ia menulis

"my objection in undertaking this reserch was to make a 'reading' of the qur'an that would be meaningful to women living in the modern era."(Wadud, 1999)

Artinya, ia hendak melakukan reinterpretasi atau mereview al-Qur'an agar dapat relevan dengan kehidupan perempuan saat ini. Maka hal tersebut dilakukan dengan cara meleburkan dua horizon (penafsir: perempuan) dan (teks masa lalu). Horizon teks (berupa studi mengenai analisis aspek bahasa teks) dan horizon penafsir (berupa latar belakang historisnya (baik mikro, berkenaan asbab an-nuzul, maupun makro, yakni berkenaan kondisi bangsa arab saat al-Qur'an diturunkan) (Syamsuddin, 2011).

Keempat, dalam aplikasinya, Amina Wadud menegaskan perlunya reproduksi atau reinterpretasi teks al-Qur'an dalam konteks kekinian. Hal tersebut serupa dengan alasan yang dikemukakan oleh Gadamer (2010) bahwa dalam teori aplikasinya pemahaman terhadap teks tidak boleh berhenti hanya sebatas dengan makan literal teks yang dihasilkan berdasarkan pemahaman sejarah kemunculan teks tersebut, akan tetapi diharuskan untuk melanjutkan kepada pemahaman yang lebih bermakna untuk masa sekarang.

\section{Aplikasi Hermeneutika terhadap ayat Kepemimpinan}

Adapun aplikasi yang ditempuh oleh Amina Wadud dalam melakukan reproduksi ayat al-Qur'an adalah sebagai berikut, Pertama, aspek historis ayat kepemimpinan memahami aspek sosio-historis ayat. Artinya, memahami konteks ayat berdasarkan kondisi sosial budaya yang melingkupi masyarakat Arab waktu turunnya ayat al-Qur'an. Sebagai contoh, Allah Swt. berfirman: "Para lelaki adalah pemimpin bagi kaum wanita, oleh karena Allah telah melebihkan sebagian mereka (laki-laki) atas sebagian yang lain (wanita), dan karena mereka (laki-laki) telah menafkahkan sebagian dari harta mereka. Sebab itu maka wanita yang saleh, ialah yang taat kepada Allah lagi memelihara diri ketika suaminya tidak ada, oleh karena Allah telah memelihara (mereka)."

Jika dianalisis secara konteks historis ayat, maka kepemimpinan laki-laki (dalam keluarga) pada ayat di atas tidaklah normatif. Arti kata normatif dalam Kamus besar Bahasa Indonesia adalah; berpegang teguh pada norma; menurut norma atau kaidah yang berlaku. Contoh penggunaan kata; seorang ahli hukum yang baik pasti normatif (Bahasa, 2008) melainkan sosialis. Ayat yang turun di Madinah tersebut, memiliki latar belakang historis ayat, yang memang menginformasikan realitas sosial masyarakat Arab yang patriarki dan bias terhadap perempuan. Saat itu, perempuan masih dipandang sebelah mata (sebatas alat reproduksi) (Wadud, 1999). Gerak langkah mereka juga dibatasi hanya boleh berada di dalam rumah, dan laki-lakilah yang menghidupinya (Engineer, 2009). Kemudian, perempuan juga tidak diharapkan dan diwajibkan mencari nafkah dan memelihara keluarga. Kaum laki-lakilah yang menjadi penentu dalam segala hal termasuk nafkah/infak. 
Karena mereka diberi kelebihan yang telah Allah jelaskan dalam ayat tersebut dengan kata 'Faddala' (Syamsuddin, 2011). 'Faddala' (kelebihan yang Allah berikan pada laki-laki), menurut Wadud kelebihan tersebut adalah kelebihan materi. Allah telah memberikan bagian laki-laki atas perempuan 2:1 dalam warisan. Jika kelebihan yang dimaksud ialah materi, maka hal tersebut tidaklah absolut (Wadud, 1999). Oleh karena itu, ayat tersebut tidaklah normatif, melainkan sosialis, ia hanya menggambarkan realitas sosial masyarakat Arab yang patriarki terhadap perempuan. Jika konteks sosial itu berubah, maka doktrin ayat tersebut juga akan ikut berubah (Subhan, 1999).

Memasuki konteks modern dengan struktur sosial yang berbeda. Penafsiran mengenai ayat 'kepemimpinan' di atas perlu diubah. Agar ayat tersebut tidak stagnan, dan relevan untuk saat ini dan masa yang akan datang. Sang penafsir harus mampu meleburkan horizon kondisi teks lampau dengan horizon prasangka penafsir pada konteks kekiniannya, dan kemudian melakukan reproduksi makna teks, agar makna ayat tersebut dapat berguna dengan semangat modern. Karena, jika melihat konteks kekinian, dengan strukur sosial masyarakat modern saat ini, dimana tidak sedikit wanita yang berkiprah di ranah publik dan bersanding dengan laki-laki dalam bekerja. Maka wanita pasti telah sejajar atau bisa lebih superior terhadap laki-laki, dan dapat memainkan peran yang dominan memimpin pada ranah keluarganya sebagaimana yang diperankan oleh laki-laki (Wadud, 1999). Dengan demikian reproduksi makna mengenai 'arrijalu qawwamuna 'ala an-nisa' $i$ ' menjadi urgen bagi para penafsir saat ini.

Namun, perlu diketahui, analisis sosiohistoris teks yang diterapkan Amina Wadud sejatinya berlawanan dengan tradisi tafsir para ulama. Pendekatan tafsir tersebut tidaklah lahir dari tradisi tafsir Islam, melainkan dari tradisi Barat yang dikembangkan oleh para orientalis yang memang anti Islam. Dalam hal ini Carl W. Ernest dan Richard C. Martin (2010) menyatakan, "Historically Speakig, what we today call Islamic Studies emerged from Orientalism, the erudite study of texts and ideas that became a highly developed field in the nineteenth and twentieth centuries in Europe and the United States."

Sedangkan dalam tradisi penafsiran para ulama Islam terdapat istilah penafsiran berbasis analisis asbab an-nuzul ayat yang telah disepakati selama berabad-abad. Dan darinya lahir sebuah kesepakatan bahwa 'al-'Ibratu bi 'Umum al-Lafdz La bi Khusus as-Sabab' (Al-Suyuthi, 2003). Keumuman lafaz ayat yang memiliki asbab annuzul dalam al-Qur'an, yang diturunkan saat kejadian tertentu dan untuk golongan tertentu, sejatinya berlaku untuk golongan tersebut dan juga untuk golongan-golongan lain dan seterusnya. Artinya, jika ayat tersebut berupa perintah atau larangan, maka keduanya tidak hanya berlaku untuk saat itu saja, akan tetapi ia akan terus menerus berlanjut walau keadaan zaman terus berubah (AlSuyuthi, 2003).

Selain itu, karena bersumber dari tradisi Barat, pendekatan Islam secara historis berimplikasi pada anti otoritas agama. Dalam hal ini, pendekatan tersebut sangat menekankan pada aspek relativisme pemahaman keagamaan. Pemahaman manusia terhadap ajaran agamanya adalah relatif dan terkait sosial budaya tertentu (Husaini, 2009). Jika hal ini diterapkan, tidak ada ajaran Islam yang bersifat tetap atau final, dan akhirnya akan berujung pada pemusnahan ajaran Islam. Dalam hal ini Maryam Jameela (1994) dalam bukunya mengatakan, "The imitation of Western ways of life based on their materialistic, 
pragmatic, and secular philosophies can only lead to the abandobment of Islam."

Kedua, aspek bahasa makna "Qawwam" Amina Wadud merelatifkan penafsiran mufassir konvensional. Mereka cenderung mendiskriminasi golongan perempuan dengan mengartikan 'qawwam' sebagai 'pemimpin'. Dalam hal ini sebagai contoh, Ibnu Katsir menjelaskan kata 'arrijalu qawwamuna 'ala an-nisa' $i$ ' ia mengatakan: "Lelaki adalah pemimpin, pembesar dan hakim bagi perempuan serta pendidik baginya apabila dia menyimpang, karena lelaki lebih utama daripada perempuan."

Lelaki lebih baik daripada dia..." Amina Wadud, menyatakan bahwa laki-laki layak dikatakan sebagai 'qawwam' atas perempuan dalam rumah tangga jika mempu memenuhi dua syarat, pertama: jika laki-laki mampu memberikan kelebihan materi yang mereka miliki. Kedua: Jika laki-laki mampu mencukupi perempuan dengan harta bendanya (Wadud, 1999). Artinya jika lakilaki tersebut mampu menafkahi perempuan maka ia layak dikatakan sebagai 'qawwam' dalam keluarga. Jadi, 'qawwam' lebih tepat jika diartikan sebagai 'pemberi nafkah'. Sebaliknya, jika syarat tersebut tidak terpenuhi, maka laki-laki tidak berhak 'qawwam' atas perempuan (Wadud, 1999). Dengan demikian, kepemimpinan laki-laki terhadap perempuan tidaklah absolut melainkan relatif.

Akan tetapi, kaidah analisis secara bahasa yang diterapkan Amina Wadud di atas cendrung berdasarkan opini subyektifnya. Hal tersebut tentunya keluar dari ketetapan ajaran Islam yang disepakati para ulama. Tradisi penafsiran bi alIjtihad atau bi al-Ra'yi (ijtihad, pendapat) memang benar adanya dalam ajaran Islam. Namun tidak berarti seseorang dapat mengartikan semaunya sendiri dalam menafsirkan ayat-ayat al-Qur'an. Penafsiran tersebut diperbolehkan selama tidak keluar dalam kandungan tafsir menurut ijtihad para mufassir terdahulu (Shalahuddin, 2012). Dalam hal ini al-Imam al-Suyuthi menegaskan, jika terdapat segolongan kelompok berpegang teguh terhadap madzhab bathil yang menafsirkan hanya berdasarkan opininya semata, dan tanpa mengikutsertakan pendapat atau penafsiran para sahabat dan tabi'in di dalamnya, maka penafsiran tersebut batal dan tidak dibenarkan (Al-Suyuthi, 2003). Dengan demikian, Amina Wadud secara jelas menerapkan metode yang salah dalam penafsirannya. Ia terpengaruh dengan metode yang bersumber dari Barat yang sebelumnya digunakan untuk mengkritisi Bible (hermeneutika). Selain itu, dalam penafsiran yang ia lakukan cendrung berdasarkan opini semata tanpa melihat ijtihad penafsiran para ulama.

Kesalahan berikutnya, selain penafsiran yang berdasarkan opini, Amina Wadud juga sejatinya terpengaruh dengan konsep yang dilahirkan Barat, yaitu kesetaraan. Sebagaimana yang telah dijelaskan di muka, karena menggunakan pendekatan kesetaraan, maka ia sangat merelatifkan makna 'qowwam' sebagai 'pemimpin' dalam keluarga. Sehingga berupaya menafsirkan ulang agar kedudukan perempuan bisa setara dengan lakilaki untuk dewasa ini. Ide terebut bukanlah hal baru, konsep kesetaraan sejatinya bermula dari ideologi Marxisme Barat. Bagi kelompok Marxis, istitusi keluarga dianggap penyebab utama munculnya segala ketimpangan sosial, terutama antara suami dan istri. Oleh karenanya muncul upaya untuk mewujudkan kesetaraan gender dengan memberikan kebebasan bagi perempuan yang tertindas (Zubaidi, 2013). Dengan demikian penafsiran Amina Wadud sejatinya bertujuan ingin menyamai konsep ideologi Barat (kesetaraan) dan kemudian dipaksakan agar relevan dengan sumber ajaran Islam yaitu al-Qur'an. Padahal penafsiran yang dipaksakan untuk basis tujuan sebagaian 
golongan tertentu sangat ditolak dalam tradisi Islam (Al-Suyuthi, 2003).

\section{Kesimpulan}

Hermeneutika Hans Goerge Gadamer jelas bermasalah, Hermeneutika modern yang berasal dari German tersebut tidak pernah digagas untuk kajian Islam. Asal mulanya ia merupakan produk teologi Kristen Protestan yang ingin lepas dari otoritas Gereja. Schleiermacher menerapkannya dalam kajian kritis Bible, lalu dilanjutkan oleh Heidegger dan Gadamer dalam kajian sastra dan naskah-naskah kuno. Dengan demikian hermeneutika modern tidaklah cocok jika digunakan untuk menggantikan ilmu tafsir dalam tradisi Islam karena ia bersumber dari tradisi ahlul kitab dalam memahami kitab suci mereka. Jika hermeneutika dipaksakan untuk menafsirkan ayatayat al-Qur'an, maka sama saja ingin menjadikannya sebagai alat untuk mengkritisi ayatayat dalam al-Qur'an.

Ini pun disebabkan oleh Nilai relativisme Barat tidak akan terelakkan, peran ulama dalam menafsirkan al-Qur'an mulai dikritisi, dan subyektifitas tafsir yang berasaskan tujuan tertentu sangat terlihat didalamnya. Selain itu, karena bersumber dari outsider Islam, hermeneutika akan selalu mengkritisi penafsiran al-Qur'an, layaknya kristen Barat menggunakan hermeneutika sebagai alat untuk mengkritisi Bible mereka. Hal tersebut dikarenakan berbagai macam problemtika dalam Bible. Teori hermeneutika beangkat dari persoalan teks Bible dan teks-teks sastra yang dikarang oleh manusia yang diwarnai aspek-aspek sosial-budaya. Hal tersebut tidaklah kita temukan dalam al-Qur'an. Jika diterapkan sama saja menurunkan derajat alQur'an dari firman tuhan menjadi kalam manusia.

\section{Daftar Pustaka}

Al-Suyuthi, J. al-D. (2003). al-Itqan Fi 'Ulum alIntizar - Vol. 27 No. 2 (2021)
Qur'an. Daar al-Kitaab al-'Arabiyyah.

Arif, S. (2008). Orientalis dan Diabolisme Pemikiran. Gema Insani Press.

Audi, R. (1999). The Cambridge Dictionary of Philosophy, (Second). Cambridge University Press.

Bachtiar, T. A. (2017). Pertarungan Pemikiran Islam di Indonesia kritik-kritik terhadap islam liberal dari HM. Rasjidi sampai INSIST. Pustaka Al-Kautsar.

Bahasa, T. R. K. P. (2008). Kamus Bahasa Indonesia. Pusat Bahasa.

Emst, C. W. (2010). Rethinking Islamic Studies. Universitiy of South Carolina Press.

Engineer, A. A. (2009). Islam dan Teologi Pembebasan terj: Agung Prihantoro. Pustaka Pelajar.

Faiz, F. (2015). Hermeneutika Al-Qur'an tematema Kontroversial,. Kalimedia.

Gadamer, H.-G. (1975). Truth and Method. Continum.

Gamader, H. G. (n.d.). Truth and Method Terj: Joel Weinsheimer and Donald G. Marshall. Continum.

Gamader, H. G. (2010). Kebenaran dan Metode pengantar filsafat hermeneutika. Kanisius.

Hardiman, B. (2015). Seni Memahami Hermeneutik dari Schleiermacher sampai Derrida (Second). Kanisius.

Hardiman, F. B. (2012). Melampaui positivisme dan modernitas. Kanisius.

Husaini, A. (2005). Wajah peradaban Barat: dari hegemoni Kristen ke dominasi sekular-liberal. Gema Insani.

Husaini, A. (2009). Kajian Islam Historis dan Aplikaisnya dalam Studi Gender. Islamia, 05(01).

Husaini, A. (2010). Jawaban Ilmiah Bentengi alQur'an. Islamia.

Husein, 'Imad Ali 'Abdu Sami.' (2004). al-Taisirfi Ushul wa al-Tijahat al-Tafsir. Dar-al-Amyan.

Irsyadunnas. (2017). Hermeneutika Femnisme dalam pemikiran tokoh Islam Kontemporer. Calpulis.

Jameela, M. (1994). Islam versus The West. Abul Qasim Publishing house.

Kaprisma, H. (2011). Cakrawala Historis pemahaman: wacana hermeneutika hans georg gadamer. Literasi, 01(02).

Kushidayati, L. (2014). Hermeneutika Gadamer 
dalam Kajian Hukum. YUDISIA, 05(04).

Lestari, L. (2014). Abraham Geiger dalam Kajian al-Qur'an. Suhuf, 07(01).

Muslim, A. al-H. (2014). al-Jami' as-Shahih alMusamma Shahih Muslim. Dar al-Afaq alJadidah.

Nayed, A. A. (1994). Interpretation as the Engagement of Operational Artifacts : Operational Hermeneutics.

Palmer, R. E. (1977). Hermeneutics: Interpretation Theory in Schleiermacher, Dilthey, Heidegger, and Gadamer, (4th ed.). Northwestern University Press,.

Preus, A. (2007). Historical Dictionary of ancient Greek Philosophy, . Scarecrow Press.

Rahardjo, M. (2007). Hermeneutika Gadamerian Kuasa Bahasa dalam Wacana Politik Gus Dur. UIN Malang Press.

Shalahuddin, H. (2007). Al-Qur'an Dihujat. AlQalam.

Shalahuddin, H. (2012). No TitleKredibilitas Ilmu Tafsir dalam Menegakkan Konsep Wahyu alQur'an. Islamia, 04(01).

Sibawahi. (2007). Hermeneutika al-Qur'an Fazlur Rahman. JALASUTRA.

Sofyan. (2014). Hermeneutika Gamader dan Relevansinya dengan tafsir. Farabi, 11(02).

Subhan, Z. (1999). Tafsir Kebencian Studi Bias Gender dalam Tafsir Qur'an. LKiS.

Sugiyono. (2012). Metode Penelitian Kuantitatif, Kualitatif dan $R \& D$. Alfabeta.

Syamsuddin, S. (2011). Upaya Integrasi Hermeneutika Kajian al-Qur'an dan Hadist (Teori dan Aplikasi). UIN Sunan Kalijaga.

Taliaferro, C. (2010). A Dictionary of Philosophy of Religion. The Tower Building.

Wadud, A. (1999). Qur'an and Women Rereading the Sacred Text From a Woman's Perpective,. Oxford University Press.

Wan Daud, W. M. N. (2004). Tafsir dan Ta'wil sebagai Metode Ilmiah. Islamia, 01(01).

Zarkasyi, H. F. (2004). Menguak Nilai dibalik Hermeneutika. Islamia, 01(01).

Zubaidi, S. (2013). Kritik Epistemologi dan Model Pembacaan Kontemporer. LESFI. 